\title{
Levels of Vitamins and Homocysteine in Older Adults with Alzheimer Disease or Mild Cognitive Impairment in Cuba
}

\author{
Yeneisy Lanyau-Domínguez MS PhD, Consuelo Macías-Matos MS PhD, Juan de Jesús Llibre-Rodríguez MD PhD DSc, \\ Gisela María Pita-Rodríguez MD MS, Ramón Suárez-Medina MD, María Eugenia Quintero-Alejo, \\ Lisseth Noriega-Fernández MD MS, Milagros Guerra-Hernández MD MS, Marina Calvo-Rodríguez MD MS, \\ Yvón Sánchez-Gil MD MS, Milagros García-Klibanski MD MS, Dania Herrera-Javier, Caridad Arocha-Oriol, \\ Maybe Díaz-Domínguez
}

\begin{abstract}
INTRODUCTION Age-related cognitive disorders, including Alzheimer disease, are among the main causes of disability and dependence in older adults worldwide. High blood homocysteine levels (hyperhomocysteinemia) are a risk factor for diseases whose metabolism involves different B vitamins. Antioxidant vitamins provide a protective effect by mitigating oxidative stress generated by these diseases. Epidemiological studies have presented varying results on the relationships between blood levels of these vitamins and such cognitive disorders.
\end{abstract}

OBJECTIVE Evaluate the association of vitamin and homocysteine levels with mild cognitive impairment and Alzheimer disease in a group of Cuban older adults.

METHODS A cross-sectional study was conducted in Havana, Cuba, of 424 persons aged $\geq 65$ years: 43 with Alzheimer disease, 131 with mild cognitive impairment, and 250 with no signs of cognitive impairment. Dementia was diagnosed using criteria of the International 10/66 Dementia Research Group and Diagnostic and Statistical Manual of Mental Disorders (DSM IV), and mild cognitive impairment was diagnosed using Petersen's criteria. Blood levels of vitamins (thiamine, B-2, folate, B-12, C and A) and homocysteine were measured by standard procedures. Analysis of variance for continuous variables and percentage comparison tests for dichotomous variables were used to compare groups.

\section{INTRODUCTION}

Dementia and its most common form, Alzheimer disease (AD), constitute one of the century's main health problems due to global population aging. These conditions are among the leading causes of disability and dependence in older adults around the world, with important implications for morbidity, quality of life, healthcare costs and mortality.[1,2] WHO estimated that some 50 million people suffered dementia in 2019 and that this figure will reach 82 million by 2030 , and 152 million by 2050 .[1]

$A D$ is characterized by progressive decline of cognitive functions and irreversible loss of neurons and their synapses, especially in the structures responsible for memory: the hippocampus and the cerebral cortex.[2] An estimated 170,000 Cubans suffered

\section{IMPORTANCE}

This is the first study in Cuba to examine vitamin and homocysteine levels in older adults with Alzheimer disease or mild cognitive impairment, and results show a relationship between these nutritional indicators and the cognitive disorders.
RESULTS Persons with Alzheimer disease presented significantly lower levels of vitamins B-2, C and A than healthy participants ( $p$ $<0.05$ ). Homocysteine levels were significantly higher in those with Alzheimer disease and mild cognitive impairment than in participants with no cognitive impairment $(p<0.05)$. Statistically, levels of thiamine, folic acid, and vitamin B-12 were not significantly different across groups. Compared with those without cognitive impairment, prevalence rates $(P R)$ in the Alzheimer group were significantly higher for hyperhomocysteinemia $(P R=3.26 ; 1.84-5.80)$ and deficiency of all $B$ vitamins: thiamine $(P R=1.89 ; 1.04-3.43), B-2(P R$ $=2.85 ; 1.54-5.26)$, folate $(P R=3.02 ; 1.53-5.95), B-12(P R=2.21$; 1.17-4.19), vitamin $C(P R=3.88 ; 2.12-7.10)$ and $A(P R=5.47$; 3.26-9.17). In mild cognitive impairment, prevalence rates were significantly higher for hyperhomocysteinemia $(P R=1.42 ; 1.08-1.87)$, vitamin $B-2$ deficiency $(P R=1.70 ; 1.24-2.32)$ and vitamin $A$ deficiency $(P R=1.88 ; 1.05-3.38)$.

CONCLUSIONS Hyperhomocysteinemia and various vitamin deficiencies are related to Alzheimer disease and mild cognitive impairment. Longitudinal studies are needed to further elucidate the relationship between different nutritional biomarkers and dementia. A better understanding of this relationship could provide a basis for therapeutic and preventive strategies.

KEYWORDS Vitamins, homocysteine, geriatrics, Alzheimer disease, cognitive impairment, Cuba

from dementia in 2019, and it is estimated that this figure will have a $76 \%$ increase and reach 300,000 cases by 2040 .[3] In recent years, dementia and $A D$ taken together have been the sixth leading cause of death in Cuba for both sexes.[4,5]

Another cognitive disorder of interest is mild cognitive impairment $(\mathrm{MCl})$, considered the gateway to dementia (proportion of conversion to dementia is $10 \%-15 \%$ of $\mathrm{MCl}$ persons annually). [6] AD is an illness with multi-source etiology involving various factors, both genetic and environmental. From $1 \%$ to $5 \%$ of cases are hereditary. Risk factors include age (it is more common after age 65), sex (more commonly affects women), low educational and employment levels, depression, smoking, and genetic presence of the apolipoprotein epsilon 4 allele (APOE $\varepsilon 4$ ), especially in the case of homozygosity. Vascular risk factors (including hypertension, diabetes, hypercholesterolemia and obesity), heart disease, and stroke at mid-life increase the risk of vascular dementia and Alzheimer disease, while physical activity and healthy diet are protective factors. $[2,7,8]$

Homocysteine (Hcy) is a sulfur-containing amino acid that plays a crucial role in transfer of methyl groups in cellular metabolism. Its high levels present a risk factor for heart disease and stroke. In systematic reviews and meta-analyses of relevant epidemiological 
studies (mostly prospective and case-control), high plasma levels of Hcy represent a modifiable risk factor for cognitive dysfunction and AD.[9-11]

The B-group vitamins (B-2, B-6, folic acid, B-12) are involved in Hcy metabolism. Deficiencies in folate and vitamin B-12 (and to a lesser degree vitamin B-6) are associated with increased homocysteine levels in plasma; it has even been proposed that hyperhomocysteinemia be used as an indicator of these vitamin deficiencies.[10-13] Folic acid and vitamin B-12 intervene in cognitive activity through other functions. Folate deficiency affects synthesis of nuclear and mitochondrial DNA, causing neuronal deterioration and cellular death in areas of the brain involved in $A D$; this deficiency can lead to hypomethylation in regions that modulate expressions of genes presumably involved in $A D$ pathogenesis.[14,15] Vitamin B-12 also acts as a cofactor in the enzyme methylmalonyl-CoA mutase, and B-12 deficiency affects synthesis of fatty acids and can lead to cognitive impairment.[16]

Several epidemiological studies have examined the relation of $B$ vitamins and antioxidant levels with cognitive function and $A D$ risk, but results are inconclusive. $[8,16,17]$

In 2000, vitamin B deficiencies were found in Cuba's older adult population.[18] Some older adults' infrequent consumption of foods including proteins, vegetables, fruit and other poor dietary habits[19] may cause these deficiencies and may be related to their cognitive disorders. Our study's hypothesis is that vitamin deficiencies and Hcy are associated with cognitive impairment. This research aims to evaluate the relationship of homocysteine and vitamin levels with $\mathrm{MCl}$ and $\mathrm{AD}$ in older Cuban adults.

\section{METHODS}

Type of study and participants An analytical cross-sectional study was conducted in a randomly selected sub-sample of 174 individuals with cognitive impairment (131 with $\mathrm{MCl}$ and 43 with $A D$ ) and 250 individuals with no cognitive impairment from the prospective longitudinal Aging and Alzheimer Study. The Aging and Alzheimer Study launched in 2003 by the Medical University of Havana's Alzheimer Research Group, studied the disease in Cuban adults aged $\geq 65$ years. The participants reside in four health areas in Havana: Marianao (in the 27 de Noviembre and Carlos Manuel Portuondo Polyclinics), Lisa (Cristóbal Labra Polyclinic), 10 de Octubre (14 de Junio Polyclinic) and Playa (Ana Betancourt Polyclinic). Participants were recruited through family physicians in the respective health areas and the Cuban 10/66 Dementia Research Group. Clinical and biochemical evaluations were done for all 424 participants. Evaluators did not know the subjects' $\mathrm{MCl}$ or $\mathrm{AD}$ status.[20,21]

Inclusion criteria Older adults who gave their written consent to participate.

Exclusion criteria Presentation of the following disorders: intestinal malabsorption, cancer, hepatic diseases, chronic kidney disease, decompensated diabetes mellitus or any other condition indicating cognitive impairment such as epilepsy, psychiatric disorders of the psychotic type or intellectual disability, cranial fracture, encephalic vascular event (thrombosis, ischemia, stroke) or other type of dementia.
Variables Table 1 presents a summary of variables.

Clinical evaluation for $\mathrm{MCl}$ and $\mathrm{AD}$ diagnosis We used the tools developed by the Cuban 10/66 Dementia Research Group, including a questionnaire on sociodemographic features, health status, lifestyle and risk factors.[20] Dementia was diagnosed using the international 10/66 criteria and algorithm, validated in 26 countries (including Cuba),[20] which includes:

- Clinical interview structured on the study participant's mental state analyzed through a computerized algorithm (AGECAT)[22]

- Interview with a reliable informant (CSI-D RELSCORE)[23]

- Community dementia screening tool (CSI-D COGSCORE)[23]

- Test for verbal fluency and repetition of CERAD modified-words list (10 words)[24]

- Additional information on early dementia and its development according to information provided by the 10/66 dementia diagnostic algorithm, its sub-types, history and etiology[25]

DSM-IV criteria[26] of the American Psychiatric Association were also used to diagnose dementia. $\mathrm{MCl}$ was diagnosed using Petersen's criteria.[27]

Clinical evaluations were conducted by medical specialists in the Medical University of Havana's Alzheimer Research Group, who received prior training based on earlier studies. Evaluation results were used to classify participants in three groups: those with $\mathrm{MCl}$, persons with $A D$, and those with no cognitive impairment.

Biochemical evaluation Samples of approximately $20 \mathrm{~mL}$ of blood were extracted intravenously after fasting; one aliquot was collected without anticoagulant and one aliquot in tubes containing ethylenediaminetetraacetic acid (EDTA). Table 1 presents the cutoff points used for the different biochemical variables. All techniques were performed in compliance with the respective quality control standards.

A volume of $0.5 \mathrm{~mL}$ of plasma plus anticoagulant was treated with an equal volume of metaphosphoric acid and frozen to $-80{ }^{\circ} \mathrm{C}$ for determination of vitamin $\mathrm{C}$ by spectrophotometry.[30] Other aliquots of plasma were used to quantify homocysteine through the enzymatic oxidation of NADH to NAD+,[29] with a commercial diagnostic kit C02257/3 (C.P.M. Diagnostic Research SAS, Italy). Vitamin A was quantified in an aliquot of plasma by high-resolution liquid chromatography.[31]

Vitamin B-2 levels were calculated by stimulating the enzyme glutathione reductase in erythrocytes obtained after plasma separation.[32] Vitamin B-1 and B-2 levels were measured by determining the effect of thiamine pyrophosphate[33] and the activation coefficient of the enzyme glutathione reductase through the activities of transketolase and erythrocyte glutathione reductase activity coefficient (EGRAC)[32] respectively; these enzymes are indirect indicators of the availability of circulating vitamins since enzymatic activity increases due to deficiency in levels of both vitamins.

Serum obtained by centrifuging the blood without anticoagulant was conserved at $-20^{\circ} \mathrm{C}$. Quantification of serum folate and vitamin B-12[34] was determined through electrochemiluminescence immunoassay using commercial diagnostic kits (Roche Diagnostics Gmb, Germany). 
Table 1: Study variables

\begin{tabular}{|c|c|c|}
\hline VARIABLE & INDICATOR & CRITERIA \\
\hline \multicolumn{3}{|l|}{ Cognitive } \\
\hline Diagnosis of $A D$ & $\begin{array}{l}\text { 10/66 diagnosis criteria and } \\
\text { algorithm[22-25]- DSM-IV } \\
\text { criteria[26] }\end{array}$ & If criteria are met \\
\hline Diagnosis of $\mathrm{MCl}$ & Petersen's criteria ${ }^{1}[27]$ & If criteria are met \\
\hline \multicolumn{3}{|c|}{ Sociodemographic category } \\
\hline Sex & Female, male & \\
\hline Age & Years & \\
\hline Skin color & white, mestizo, Black & \\
\hline $\begin{array}{l}\text { Educational level } \\
\text { completed }\end{array}$ & $\begin{array}{l}\text { None; or primary, secondary } \\
\text { or university level completed }\end{array}$ & \\
\hline
\end{tabular}

Lifestyle

Smoking behavior Smoker or ex-smoker

Number of cigarettes, cigars, or

\begin{tabular}{|c|c|c|}
\hline $\begin{array}{l}\text { Alcoholic beverage } \\
\text { consumption }\end{array}$ & Risky (heavy) drinker & $\begin{array}{l}\text { If weekly alcohol consumption } \geq 14 \\
\text { units for women or } \geq 21 \text { for men }{ }^{2}[20]\end{array}$ \\
\hline \multicolumn{3}{|c|}{ Clinical exam and interview } \\
\hline Hypertension & $\begin{array}{l}\text { Self-reported and blood } \\
\text { pressure measurements }\end{array}$ & $\begin{array}{l}\text { Systolic pressure } \geq 140 \mathrm{mmHg} \text { and/ } \\
\text { or diastolic pressure } \geq 90 \mathrm{mmHg}[20]\end{array}$ \\
\hline Diabetes mellitus & $\begin{array}{l}\text { Self-reported and fasting } \\
\text { blood glucose }\end{array}$ & $\begin{array}{l}\text { Fasting blood glucose } \geq 7.0 \\
\mathrm{mmol} / \mathrm{L}[20]\end{array}$ \\
\hline $\begin{array}{l}\text { Family history of } \\
\text { dementia }\end{array}$ & Self-reported & If affirmative[20] \\
\hline \multicolumn{3}{|l|}{ Biochemical } \\
\hline Vitamin B-1 & TPPE $^{3}$ & $\begin{array}{ll}\text { Normal } & \text { TPPE } \leq 15 \% \\
\text { Marginal } & 15<\text { TPPE } \leq 25 \% \\
\text { Deficient } & \text { TPPE }>25 \%[28]\end{array}$ \\
\hline Vitamin B- 2 & EGRAC $^{3}$ & $\begin{array}{ll}\text { Normal } & E G R A C \leq 1.30 \\
\text { Marginal } & 1.30<E G R A C<1.80 \\
\text { Deficient } & E G R A C \geq 1.80[28]\end{array}$ \\
\hline Vitamin C & Vitamin C level & $\begin{array}{ll}\text { Normal } & >0.3 \mathrm{mg} / \mathrm{dL} \\
\text { Marginal } & 0.2-0.3 \mathrm{mg} / \mathrm{dL} \\
\text { Deficient } & <0.2 \mathrm{mg} / \mathrm{dL}[28]\end{array}$ \\
\hline Vitamin A & Retinol level & $\begin{array}{ll}\text { Low } & 20 \leq \mathrm{RL} \leq 30 \mu \mathrm{g} / \mathrm{dL} \\
\text { Marginal } & 10 \leq \mathrm{RL}<20 \mu \mathrm{g} / \mathrm{dL} \\
\text { Deficient } & \mathrm{RL}<10 \mu \mathrm{g} / \mathrm{dL}[28]\end{array}$ \\
\hline Serum folate & Serum folate level & Deficient $<3.1 \mathrm{ng} / \mathrm{mL}[28]$ \\
\hline Vitamin B-12 & Vitamin B-12 level & Deficient $<240$ pg/mL[28] \\
\hline Homocysteine & Homocysteine level & Homocysteine $>15 \mu \mathrm{mol} / \mathrm{L}[29]$ \\
\hline
\end{tabular}

AD: Alzheimer disease;

MCI: Mild cognitive impairment;

RL: Retinol level;

EGRAC: Erythrocyte glutathione reductase activation coefficient. Based on calculation of the degree of stimulation of erythrocyte glutathione reductase through parallel measurement of enzymatic activity with in vitro addition of its coenzyme flavin adenine dinucleotide (stimulated activity of the enzyme) and without the coenzyme (basal enzymatic activity).

TPPE: Thiamine pyrophosphate effect. Based on calculation of degree of transketolase enzyme stimulation through parallel measurement of enzymatic activity with addition of its coenzyme in vitro thiamine

pyrophosphate (TPP) (activity stimulated by the enzyme) and without the coenzyme (basal enzymatic activity).

${ }^{1}$ Criteria developed by Petersen;[27] presence of:

a) Subjective memory complaints

b) Pathological performance in neuropsychological tests

c) No interference of memory impairment in subject's work / social / daily life

d) Remaining cognitive functions preserved

e) Absence of dementia

f) Absence of other pathologies that could explain memory impairment (depression, endocrine disease, etc.)

${ }^{2}$ Units of alcohol established according to beverage type: 1 glass of beer ( $250 \mathrm{~mL}=2$ units), 1 shot of liquor

$(22 \mathrm{~mL}=2$ units $)$ or 1 glass of wine $(175 \mathrm{~mL}=2$ units $)$ and 1 bottle of liquor $(1000 \mathrm{~mL}=32$ units $)$.

${ }^{3}$ Increases in TPPE and EGRAC lead to greater deficiencies in Vitamin B-1 and B-2 levels, respectively.
Due to insufficient sample volume, we quantified serum folate, B-12 and thiamine in $92 \%$ of the samples; vitamin B-2 in $89 \%$; vitamin $\mathrm{C}$ in $91 \%$; homocysteine in $90 \%$; and vitamin $\mathrm{A}$ in $81 \%$ of the samples.

Ethical considerations The study's protocol was approved by the Scientific Council and Research Ethics Committee of the National Hygiene, Epidemiology and Microbiology Institute and the Medical University of Havana. The study was conducted in accordance with the World Medical Association's Declaration of Helsinki and its ethical principles for medical research involving human subjects.[35] The scientific and social features and importance were explained to all participants and family members representing them, and their oral and written consent was obtained. In the case of older adults unable to give their consent, approval was sought from the family member responsible for their care.

Data processing and analysis Means and standard deviations were calculated to describe quantifiable variables and absolute frequencies and percentages for qualitative variables. An analysis of covariance was applied to identify the main or interactive effects of covariables (age and family history of dementia, which differed across groups) on vitamin means; none were determined to be significant $(p>0.05)$.

To compare the three groups $(A D, M C l$, and without cognitive impairment), a one-way analysis of variance was conducted, with a posteriori tests to identify different groups using parametric tests or their non-parametric alternatives depending on whether they met the assumptions of group normality and homoscedasticity. A significance level of $p=0.05$ was adopted. The test of homogeneity between groups was applied to the biochemical variables. The Pearson correlation was calculated as a measure of linear association of homocysteine levels with folate, vitamins B-12 and B-2. The prevalence of hyperhomocysteinemia was calculated as well as the prevalence of vitamin deficiencies, taking as reference the group with no cognitive impairment (with confidence intervals estimated at 95\%). The statistical procedure used SPSS Statistics version 20 software (IBM, USA).

\section{RESULTS}

The average age was 78 years old in the group with no cognitive impairment, 79.5 in the $\mathrm{MCl}$ group and 82.8 in the $A D$ group. 
Table 2: Sociodemographic and clinical features of participants

\begin{tabular}{|c|c|c|c|}
\hline \multirow[t]{2}{*}{ Feature } & $\begin{array}{c}\text { No cognitive } \\
\text { impairment } \\
n=250\end{array}$ & $\begin{array}{c}\text { Mild cognitive } \\
\text { impairment } \\
n=131\end{array}$ & $\begin{array}{c}\text { Alzheimer } \\
\text { disease } \\
n=43 \\
\end{array}$ \\
\hline & $\mathbf{N}(\%)$ & $\mathbf{N}(\%)$ & $\mathbf{N}(\%)$ \\
\hline \multicolumn{4}{|l|}{ Sex } \\
\hline Male & $78(31.2)$ & $46(35.1)$ & $12(27.9)$ \\
\hline Female & $172(68.8)$ & $85(64.9)$ & $31(72.1)$ \\
\hline \multicolumn{4}{|l|}{ Age group (years) } \\
\hline $65-69$ & $2(0.8)$ & $0(0)$ & $0(0)$ \\
\hline $70-74$ & $76(30.4)$ & $30(22.9)$ & $4(9.3)$ \\
\hline $75-79$ & $83(33.2)$ & $41(31.3)$ & $13(30.2)$ \\
\hline$\geq 80$ & $89(35.6)$ & $60(45.8)$ & $26(60.5)$ \\
\hline \multicolumn{4}{|l|}{ Skin color } \\
\hline White & $174(69.6)$ & $88(67.2)$ & $30(69.8)$ \\
\hline Mestizo & $32(12.8)$ & $11(8.4)$ & $6(14.0)$ \\
\hline Black & $44(17.6)$ & $32(24.4)$ & $7(16.3)$ \\
\hline \multicolumn{4}{|c|}{ Educational level completed } \\
\hline $\begin{array}{l}\text { None or incomplete } \\
\text { primary }\end{array}$ & $64(25.6)$ & $32(24.4)$ & $17(39.5)$ \\
\hline Primary & $86(34.4)$ & $50(38.2)$ & $8(18.6)$ \\
\hline Secondary & $47(18.8)$ & $26(19.8)$ & $8(18.6)$ \\
\hline University & $53(21.2)$ & $23(17.6)$ & $10(23.3)$ \\
\hline \multicolumn{4}{|l|}{ Smoking behavior } \\
\hline $\begin{array}{l}\text { Smoker or ex- } \\
\text { smoker }\end{array}$ & $116(46.6)$ & $63(48.1)$ & $20(46.5)$ \\
\hline Non-smoker & $133(53.4)$ & $68(51.9)$ & $23(53.5)$ \\
\hline \multicolumn{4}{|c|}{ Alcohol consumption } \\
\hline Yes & $7(2.8)$ & $2(1.6)$ & $4(9.3)$ \\
\hline No & $242(97.2)$ & $126(98.4)$ & $39(90.7)$ \\
\hline \multicolumn{4}{|l|}{ Hypertension } \\
\hline Yes & $183(73.2)$ & $98(74.8)$ & $31(72.1)$ \\
\hline No & $67(26.8)$ & $33(25.2)$ & $12(27.9)$ \\
\hline \multicolumn{4}{|c|}{ Glucose metabolism disorder } \\
\hline Yes & $121(49.8)$ & $72(55.4)$ & $24(58.5)$ \\
\hline No & $122(50.2)$ & $58(44.6)$ & $17(41.5)$ \\
\hline \multicolumn{4}{|c|}{ Family history of dementia } \\
\hline Yes & $28(11.2)$ & $21(16.0)$ & $11(25.6)$ \\
\hline No & $222(88.8)$ & $110(84.0)$ & $32(74.4)$ \\
\hline
\end{tabular}

$\mathrm{N}$ : Number of persons $\quad \mathrm{n}$ : number of persons evaluated. $\%: 100 \times \mathrm{N} / \mathrm{n}$.

Other sociodemographic and clinical features were similar across groups, except family history of dementia, which was more common in the groups with cognitive disorders. In all three groups, $60 \%$ of participants had a low education level (elementary school only), $47 \%$ were smokers or ex-smokers, only $3 \%$ drank alcohol, $73 \%$ had hypertension and $52 \%$ had altered glucose (Table 2).

Hcy levels varied notably across groups. The highest levels were found in the $A D$ group and $\mathrm{MCl}$ group. Only those with $A D$ had notably lower levels of vitamins $\mathrm{C}, \mathrm{A}$, and $\mathrm{B}-12$. No differences were found across the groups in levels of thiamine (B-1), folate and vitamin B-12. Vitamins B-1 and B-2 levels were lower in the most severe cases of $A D$ and $\mathrm{MCl}$. The average vitamin $\mathrm{C}$ level was lower in the AD group than in the $\mathrm{MCl}$ group (Table 3).
The prevalence of vitamin deficiency in B-2, folate, C, A and hyperhomocysteinemia were significantly more common in individuals with $A D$ than in individuals with no cognitive impairment. Vitamins B-1 and B-12 deficiencies showed the same pattern but were not statistically significant (Table 4).

For all biochemical markers, prevalence rates were higher than one and notably higher in the $\mathrm{AD}$ group than in the $\mathrm{MCl}$ group, with the exception of folate (Table 5).

\section{DISCUSSION}

The B vitamins (B-2, B-6, folic acid, B-12) are involved in Hcy metabolism. High levels of this compound are considered a risk factor for cardiovascular disease, stroke, and more recently, Alzheimer disease and vascular dementia. Deficiency of B-group vitamins, the leading cause of hyperhomocysteinemia in older adults, is influenced mainly by diet.[11-13,36]

This study confirmed that Hcy levels were significantly higher in individuals with $\mathrm{AD}$ and $\mathrm{MCl}$ and that hyperhomocysteinemia was more common in $\mathrm{MCl}$ and $\mathrm{AD}$ than in participants with no cognitive impairment. High Hcy levels are associated with cognitive impairment and AD.[10-13,36] In 17 of the 19 cohort studies included in a systematic review that evaluated the relationship between Hcy levels and AD risk, a significant association was found.[10] A meta-analysis of 68 studies confirmed that persons with $A D$ had higher levels of Hcy than those without cognitive impairment, suggesting that higher Hcy levels could be an AD risk factor.[11]

Several mechanisms have been proposed to explain the relation between Hcy and AD, including demethylation, cerebrovascular damage, oxidative stress and high levels of the ß-amyloid peptide.[9,12,36,37] Deficiencies of the vitamin B group can lead to insufficient methylation of Hcy and therefore, reduced synthesis of methionine and S-adenosylmethionine. This in turn can lead to a shortage of methyl groups that are essential for the synthesis of nucleic acids, proteins, neurotransmitters, membrane phospholipids and for metabolism of myelin, which could affect reduction of neurocognitive function. $[8,9,38]$

Excess Hcy has a detrimental effect on blood vessel walls, since the oxidation of its sulfhydryl group generates potential reactive forms, such as superoxide anions, hydrogen peroxide and hydroxyl anion, which can cause endothelial damage. The endothelial cells reduce synthesis of nitric oxide, leading to vasoconstriction and increased platelet stickiness, lipoprotein oxidation and with that, increased LDL deposits on arterial walls, activation of the coagulation cascade and limitation of blood flow, resulting in thrombosis and neuronal death.[9,12]

High Hcy levels reportedly can have a neurotoxic effect by stimulating the glutamate receptor that induces increased calcium flow to the cell's interior. As a result, neuronal toxicity from oxidative stress is amplified, leading finally to apoptosis.[9,12,37]

The increased content of oxygen radicals due to high Hcy levels can also lead to hydrolysis of the precursor protein amyloid, increased generation of the $\beta$-amyloid peptide, and formation of amyloid plaques in the neurons (one of the main characteristics of Alzheimer disease).[8,32] 
Table 3: Average homocysteine and vitamin levels in older adults by degree of cognitive impairment

\begin{tabular}{|c|c|c|c|c|}
\hline $\begin{array}{l}\text { Biochemical } \\
\text { indicator } \\
\mathbf{n}\end{array}$ & $\begin{array}{c}\text { No cognitive } \\
\text { impairment } \bar{X} \text { (SD) } \\
n=250\end{array}$ & $\begin{array}{c}\text { Mild cognitive } \\
\text { impairment } \bar{X} \text { (SD) } \\
n=131\end{array}$ & $\begin{array}{c}\text { Alzheimer } \\
\text { disease } \bar{X}(S D) \\
n=43\end{array}$ & p \\
\hline $\begin{array}{l}\text { Homocysteine }(\mu \mathrm{mol} / \mathrm{L}) \\
380\end{array}$ & $\begin{array}{r}13.6^{a}(6.5) \\
n=214\end{array}$ & $\begin{array}{r}14.6^{b}(5.7) \\
n=126\end{array}$ & $\begin{array}{r}18.0^{c}(7.7) \\
n=40\end{array}$ & 0.000 \\
\hline $\begin{array}{l}\text { Vitamin B-1 (TPPE) \% } \\
379\end{array}$ & $\begin{array}{r}12.8(12.2) \\
\mathrm{n}=214\end{array}$ & $\begin{array}{r}13.2(12.4) \\
\mathrm{n}=126\end{array}$ & $\begin{array}{r}19.6(18.6) \\
n=39\end{array}$ & 0.320 \\
\hline $\begin{array}{l}\text { Vitamin B-2 (EGRAC) } \\
372\end{array}$ & $\begin{array}{r}1.16^{\mathrm{a}}(0.12) \\
\mathrm{n}=215\end{array}$ & $\begin{array}{r}1.19^{\mathrm{ab}}(0.14) \\
\mathrm{n}=120\end{array}$ & $\begin{array}{r}1.23^{b}(0.17) \\
n=37\end{array}$ & 0.027 \\
\hline $\begin{array}{l}\text { Serum folate }(\mathrm{ng} / \mathrm{mL}) \\
391\end{array}$ & $\begin{array}{r}10.6(5.1) \\
n=228\end{array}$ & $\begin{array}{r}10.3(5.1) \\
n=126\end{array}$ & $\begin{array}{r}9.2(5.8) \\
\mathrm{n}=37\end{array}$ & 0.250 \\
\hline $\begin{array}{l}\text { Vitamin B-12 (pg/mL) } \\
391\end{array}$ & $\begin{array}{r}575.3(419.3) \\
\mathrm{n}=228\end{array}$ & $\begin{array}{r}564.3(421.3) \\
n=126\end{array}$ & $\begin{array}{r}581.5(543.2) \\
\mathrm{n}=37\end{array}$ & 0.440 \\
\hline $\begin{array}{l}\text { Vitamin C }(\mu \mathrm{mol} / \mathrm{L}) \\
386\end{array}$ & $\begin{array}{r}79.1^{\mathrm{a}}(64.0) \\
\mathrm{n}=226\end{array}$ & $\begin{array}{r}75.5^{\mathrm{a}}(45.6) \\
\mathrm{n}=122\end{array}$ & $\begin{array}{r}61.6^{b}(51.9) \\
n=38\end{array}$ & 0.043 \\
\hline $\begin{array}{l}\text { Vitamin A ( } \mu \mathrm{g} / \mathrm{dL}) \\
345\end{array}$ & $\begin{array}{r}65.5^{\mathrm{a}}(20.6) \\
\mathrm{n}=197\end{array}$ & $\begin{array}{r}63.2^{\mathrm{ab}}(21.8) \\
\mathrm{n}=111\end{array}$ & $\begin{array}{r}55.3^{b}(23.3) \\
n=37\end{array}$ & 0.039 \\
\hline
\end{tabular}

n: Number of persons evaluated; $\bar{X}$ : mean; SD: Standard deviation; TPPE: Effect of thiamine pyrophosphate in the transketolase enzyme indicator of vitamin B-1. A higher value indicates lower availability of the vitamin; EGRAC: Erythrocyte glutathione reductase activation coefficient, a biochemical indicator of vitamin: a higher value indicates lower availability of the vitamin.

a, b, ab, $\mathrm{c}$ Indicates differences between average values of the Scheffé test a posteriori for parametric analysis and the Kruskal Wallis test as a non-parametric alternative: matching letters indicate similarities and different letters indicate differences.

Table 4: Hyperhomocysteinemia and vitamin deficiency in older adults by degree of cognitive impairment

\begin{tabular}{|c|c|c|c|c|}
\hline Biochemical indicator & $\begin{array}{c}\text { No cognitive } \\
\text { impairment } \\
\mathbf{N}(\%) \\
\mathbf{n}\end{array}$ & $\begin{array}{c}\text { Mild cognitive } \\
\text { impairment } \\
\text { N (\%) } \\
\text { n }\end{array}$ & $\begin{array}{c}\text { Alzheimer } \\
\text { disease } \\
\text { N (\%) } \\
\text { n }\end{array}$ & $\begin{array}{l}X^{2} \\
(p)\end{array}$ \\
\hline $\begin{array}{l}\text { Hyperhomocysteinemia } \\
(>15 \mu \mathrm{mol} / \mathrm{L})\end{array}$ & $\begin{array}{r}56(26.2) \\
n=214\end{array}$ & $\begin{array}{r}49(38.9) \\
\mathrm{n}=126\end{array}$ & $\begin{array}{r}24(60.0) \\
n=40\end{array}$ & $\begin{array}{r}18.7 \\
(0.000)\end{array}$ \\
\hline $\begin{array}{l}\text { Vitamin B-1 deficiency } \\
\text { (TPPE >15\%) }\end{array}$ & $\begin{array}{l}92(43) \\
n=214\end{array}$ & $\begin{array}{r}61(48.4) \\
\mathrm{n}=126\end{array}$ & $\begin{array}{r}24(61.5) \\
n=39\end{array}$ & $\begin{array}{r}4.8 \\
(0.091)\end{array}$ \\
\hline $\begin{array}{l}\text { Vitamin } B-2 \text { deficiency } \\
(E G R A C>1.30)\end{array}$ & $\begin{array}{l}19(8.8) \\
n=215\end{array}$ & $\begin{array}{r}24(20.0) \\
\mathrm{n}=120\end{array}$ & $\begin{array}{r}10(27.0) \\
\mathrm{n}=37\end{array}$ & $\begin{array}{r}12.9 \\
(0.002)\end{array}$ \\
\hline $\begin{array}{l}\text { Folate deficiency } \\
(<3.10 \mathrm{ng} / \mathrm{mL})\end{array}$ & $\begin{array}{l}12(5.3) \\
n=228\end{array}$ & $\begin{array}{r}4(3.2) \\
n=126\end{array}$ & $\begin{array}{r}7(18.9) \\
n=37\end{array}$ & $\begin{array}{r}9.6 \\
(0.008)\end{array}$ \\
\hline $\begin{array}{l}\text { Vitamin B-12 deficiency } \\
(<240 \mathrm{pg} / \mathrm{mL})\end{array}$ & $\begin{array}{r}28(12.3) \\
\mathrm{n}=228\end{array}$ & $\begin{array}{r}19(15.1) \\
\mathrm{n}=126\end{array}$ & $\begin{array}{r}10(27.0) \\
\mathrm{n}=37\end{array}$ & $\begin{array}{r}4.88 \\
(0.087)\end{array}$ \\
\hline $\begin{array}{l}\text { Vitamin C deficiency } \\
(<11 \mu \mathrm{mol} / \mathrm{L})\end{array}$ & $\begin{array}{r}9(4.0) \\
n=226\end{array}$ & $\begin{array}{r}5(4.1) \\
\mathrm{n}=122\end{array}$ & $\begin{array}{r}8(21.1) \\
n=38\end{array}$ & $\begin{array}{r}12.3 \\
(0.002)\end{array}$ \\
\hline $\begin{array}{l}\text { Vitamin A deficiency } \\
(<1.05 \mu \mathrm{mol} / \mathrm{L})\end{array}$ & $\begin{array}{r}2(1.0) \\
n=197\end{array}$ & $\begin{array}{r}4(3.6) \\
n=111\end{array}$ & $\begin{array}{r}6(16.2) \\
n=37\end{array}$ & $\begin{array}{r}14.6 \\
(0.001)\end{array}$ \\
\hline
\end{tabular}

$\mathrm{N}$ : Number of persons with the value of the biochemical indicator; $\mathrm{n}$ : number of persons evaluated; $\%: 100$ $x \mathrm{~N} / \mathrm{n}$.

TPPE: Thiamine pyrophosphate effect on transketolase enzyme EGRAC: Erythrocyte glutathione reductase activation coefficient. Values of $p$ calculated by the chi-square test of homogeneity.

Independent of high Hcy levels, folic acid and vitamin B-12 also contribute to cognitive function.[14-16] Folate deficiency affects nuclear and mitochondrial DNA synthesis due to lack of methylation of purines, and impedes transformation of uracil into thymine, causing oxidative stress and generation of reactive oxygen species, followed by neuronal deterioration and cellular death in areas of the brain involved in AD.[14,15] Folate deficiency can also cause hypomethylation of regions that modulate expression of genes presumably involved in AD pathogenesis. $[14,15]$ In addition, vitamin B-12 is a cofactor of the enzyme methylmalonyl-CoA mutase; deficiency of this vitamin causes inactivation of the enzyme and accumulation of methylmalonyl-CoA, affecting fatty- acid synthesis. Cognitive impairment results from accumulation of abnormal fatty acids in neural tissue membranes.[16]

Results of several authors vary with respect to these vitamin levels in older adults with and without AD. A 30-study meta-analysis showed that plasma levels of these vitamins were significantly lower in persons with AD.[39] Another meta-analysis (of 68 studies) found that those with $A D$ had higher homocysteine levels and lower serum folate and vitamin B-12 levels in plasma than those found in persons without AD.[11] In line with our study, two other cross-sectional studies did not find significant differences in average serum folate and vitamin B-12 levels across the groups.[40,41]

We found that serum folate and Vitamin B-12 deficiencies were more prevalent in the $A D$ group, similar to several other epidemiological studies. $[13,42,43]$

Although some studies (particularly those using a cross-sectional design) have shown association, and despite the large number of cohort studies, there is still insufficient evidence to conclude an association between folate or vitamin B-12 levels and risk of cognitive impairment and dementia, as shown in the differing results in the literature. $[8,11,16]$ This is likely due to a variety of different study designs in terms of sample size, duration, lack of control for confounding variables and use of more specific biological markers, among other factors.

Vitamin B-2 plays a crucial role. Its co-enzymatic form (flavin-adenine dinucleotide, FAD) acts as a co-factor of the enzyme methylenetetrahydrofolate reductase, which metabolizes the folate participating in Hcy methylation.[8,9] A South Korean study in elders divided into three groups (normal individuals, those with $\mathrm{MCl}$ and those with $A D$ ) found that Hcy levels were inversely proportional to intake of vitamins B-2, B-6, B-12 and folate. Among $A D$ subjects, those with higher vitamin intake presented better results on several tests: the Mini-Mental State Examination-KC, CERAD-K Consortium (MMSE-KC), Boston Naming Test, Word Fluency, Word List Memory Test and Constructional Recall Test.[44] In the MCI group, those with higher vitamin B-2 intake presented better results on the MMSE-KC and Boston Naming tests.[44] These results show that vitamin B-2 is important in cognitive function.

In our research, vitamin B-1 levels were lower in individuals with $\mathrm{MCl}$ and even lower in those with $\mathrm{AD}$. Although differences in $B-1$ levels across groups were not significant, individuals with $A D$ showed greater prevalence of B-1 deficiency.

Vitamin B-1 apparently plays a role in AD pathogenesis.[45,46] AD patients reportedly have lower vitamin B-1 levels in plasma and 
Table 5: Hyperhomocysteinemia and vitamin deficiency in older adults with mild cognitive impairment and Alzheimer disease

\begin{tabular}{|l|c|c|}
$\begin{array}{l}\text { Biochemical } \\
\text { indicator }\end{array}$ & $\begin{array}{c}\text { Mild cognitive } \\
\text { impairment } \\
\text { PR (CI) }\end{array}$ & $\begin{array}{c}\text { Alzheimer } \\
\text { disease } \\
\text { PR (CI) }\end{array}$ \\
\hline Hyperhomocysteinemia & $1.42(1.08-1.87)$ & $3.26(1.84-5.80)$ \\
\hline Vitamin B-1 deficiency & $1.15(0.87-1.51)$ & $1.89(1.04-3.43)$ \\
\hline Vitamin B-2 deficiency & $1.70(1.24-2.32)$ & $2.85(1.54-5.26)$ \\
\hline Folate deficiency & $0.69(0.29-1.64)$ & $3.02(1.53-5.95)$ \\
\hline Vitamin B-12 deficiency & $1.16(0.79-1.70)$ & $2.21(1.17-4.19)$ \\
\hline Vitamin C deficiency & $1.02(0.50-2.09)$ & $3.88(2.12-7.10)$ \\
\hline Vitamin A deficiency & $1.88(1.05-3.38)$ & $5.47(3.26-9.17)$ \\
\hline
\end{tabular}

$\mathrm{Cl}$ : Confidence interval; PR: Prevalence rate; PR were calculated using individuals with no cognitive impairment as a reference group.

reduced vitamin-B-dependent activity of enzymes $\alpha$-ketoglutarate dehydrogenase and $\alpha$-transketolase in their brains and peripheral tissue.[45,46] In rats with vitamin B-1 deficiency, accumulation of the amyloid precursor protein has been observed in damaged brain regions; this provokes accumulation of the $\beta$-amyloid peptide that forms amyloid plaques, the main cause of neuronal death.[45]

Vitamin B-1 requires synthesis of acetylcholine, the neurotransmitter most commonly deficient in AD. Reduced acetylcholine synthesis has been observed in brains of rats with vitamin B-1 deficiency.[44] Multiple events are associated with vitamin B-1 deficiency. One of these is reduced activity of $\alpha$-ketoglutarate dehydrogenase, which leads to an energy deficit due to deterioration of the tricarboxylic acid cycle and reduced ATP synthesis, in addition to decreased activity of the $\mathrm{Na}^{+} / \mathrm{K}^{+}-$ATPase, resulting in high toxicity, activation of glutamate receptor, calcium input, and finally, neuronal death.[46]

Findings show that vitamin B-1 deficiency is tied to neuroinflammation, which plays a key role in $A D$ pathogenesis. When B-1 supply is deficient, reports indicate morphological glial-cell alterations, including swelling and appearance of phagocytic vacuoles; proinflammatory cytokines are also produced in vulnerable and non-vulnerable regions of the brain.[45] In animals with vitamin B-1 deficiency, increased reactive oxygen species, induction of the endothelial isoform of nitric oxide synthase and changes in superoxide dismutase levels have all been reported.[45]

Our study's results also show that plasma levels of antioxidant vitamins $C$ and $A$ were significantly lower in the $A D$ group than in those with no cognitive impairment. Vitamin A deficiency was much more common in individuals with $\mathrm{MCl}$-and especially those with $A D$ - than in those with no cognitive impairment, while vitamin $C$ deficiency occurred in individuals with $A D$. A metaanalysis of studies on eight vitamins showed that persons with $A D$ had significantly lower levels of vitamin $C, E$ and $A$ than those without cognitive impairment.[39] A cross-sectional study of older adults in Germany found significantly lower levels of vitamin C and $\beta$-carotene in individuals with dementia than in the healthy individuals.[17] Another more recent meta-analysis of studies on vitamin levels in cerebrospinal fluid showed that persons with $A D$ had significantly lower vitamin C, E, folate and B-12 levels.[47]

Other findings in studies on rats show that vitamin $C$ reduces generation of the $\beta$-amyloid peptide and acetylcholinesterase activity. Vitamin $C$ prevents endothelial impairment, one of the main factors in AD pathogenesis and progression.[48]

Recent in vitro studies have shown that vitamin A (retinol, retinal and retinoic acid) and the $\beta$-carotene provitamin inhibit the formation, extension and destabilization of $\beta$-amyloid peptide fibrils. Vitamin $A$ and $\beta$-carotene in vitro have an inhibitory effect on oligomerization of the two main types of the $\beta$-amyloid peptide, $A \beta 40$ and $A \beta 42$ (the last one is prominent in the brains of individuals with AD).[49]

In cognitive disorders, availability of antioxidant vitamins decreases, due to oxidative stress. Neural membranes are a potential target for oxidative stress damage due to their high content of polyunsaturated fatty acids vulnerable to oxidation. Lipid peroxidation can alter the membrane's composition, which is evident in Alzheimer disease. Vitamins A, C and $E$ serve as antioxidants to protect lipid precursors and membrane components against lipid peroxidation. In $A D$, the need for vitamins increases in order to compensate for their increased use.[39,47]

In this study, low levels of vitamins B-2, C and A were found in patients with $A D$ and $\mathrm{MCl}$, in line with results from other authors.[10,11,39,47] It is not possible to infer causation in these associations or even potential reciprocal causation: that is, dementia as a factor that promotes poor nutritional intake, or, inversely, the process of dementia as a result of reduced nutritional intake in older adults.[39]

One study limitation is that its cross-sectional design does not allow chronological ordering of events to be established, or, as a result, whether the nutritional indicators associated with $\mathrm{MCl}$ and $\mathrm{AD}$ can be determined to be the cause of the disease or merely a consequence of it. Due to limited resources, more specific biological markers were not used. The study's results are important because this is the first time cognitive disorders in older Cubans have been studied in relation to vitamin deficiency and hyperhomocysteinemia. Longitudinal studies are needed to further understand the relationship between different nutritional biomarkers and dementia.

\section{CONCLUSIONS}

The association of certain vitamin deficiencies and hyperhomocysteinemia with mild cognitive impairment and Alzheimer disease was confirmed in older adults in Cuba. Both these results and a range of epidemiological evidence support the close relationship between nutrition and $A D$ in Cuba's older adult population.

\section{ACKNOWLEDGMENTS}

We want to thank $\mathrm{Dr}$ Josanne Soto Matos of the Hermanos Ameijeiras Clinical-Surgical Teaching Hospital for her quantification of folic acid and vitamin B-12.

\section{FINANCING}

The study received financing from Cuba's Ministry of Public Health and the Aging and Alzheimer Project (10/66 study), the latter a collaboration between the Medical University of Havana and the Institute of Psychiatry, Psychology and Neurosciences of King's College, London, financed by Welcome Trust (GR066133) and Cuba's Ministry of Public Health. - 1 - 


\section{REFERENCES}

1. World Health Organization [Internet]. Geneva: World Health Organization; c2019. Centro de prensa. Notas descriptivas. Demencia; 2019 Sep [cited 2019 Nov 10]; [about 4 screens]. Available at: https://www.who.int/es/news-room/fact -sheets/detail/dementia. Spanish.

2. Lane CA, Hardy J, Schott JM. Alzheimer's disease. Eur J Neurol. 2018;25(1):59-70.

3. Reymond AG, Gispert EA, Llibre JJ, CastellFlorit P, Bosch R I, Llerena T. Percepción de las demencias y la intersectorialidad en el contexto del Policlínico Docente Playa. Rev Cubana Salud Pública. 2019;45(1):e1128. Spanish.

4. National Health Statistics and Medical Records Division (CU). Anuario Estadístico de Salud 2017 (Table 19). Havana: Ministry of Public Health (CU); 2018 Apr [cited 2020 Jun 2]. 206 p. Available at: https://files.sld.cu/dne /files/2018/04/Anuario-Electronico-Espa \%c3\%b1ol-2017-ed-2018.pdf. Spanish.

5. National Health Statistics and Medical Records Division (CU). Anuario Estadístico de Salud 2018 (Table 19) [Internet]. Havana: Ministry of Public Health (CU); 2019 May [cited 2020 Jun 2]. 206 p. Available at: https://files.sld.cu/bvs cuba/files/2019/04/Anuario-Electr\%c3\%b3nico -Espa\%c3\%b1ol-2018-ed-2019-compressed.pdf Spanish.

6. Vega JN, Newhouse PA. Mild cognitive impairment: diagnosis, longitudinal course, and emerging treatments. Curr Psychiatry Rep. 2014 Oct;16(10):490. DOI: 10.1007/s11920 $-014-0490-8$.

7. Prince $M$, Albanese $E$, Guerchet $M$, Prina M. Alzheimer's Disease International. World Alzheimer Report 2014. Dementia and risk reduction. An analysis of protective and modifiable factors. London: Alzheimer's Disease International; 2014

8. Prina M, Albanese E. Nutritional factors and dementia prevention. In: Prince M, Albanese E, Guerchet $M$, Prina $M$, editors. Nutrition and Dementia: a review of available research. London: Alzheimer's Disease International; 2014. p. 31-42.

9. Smith D, Refsum H. Homocysteine, B Vitamins, and cognitive impairment. Annu Rev Nutr. 2016;36:211-39.

10. Beydoun MA, Beydoun HA, Gamaldo AA, Teel A, Zonderman AB, Wang Y. Epidemiologic studies of modifiable factors associated with cognition and dementia: systematic review and meta-analysis. BMC Public Health. 2014 Jun 24;14:643.

11. Shen L, Ji H. Associations between homocysteine, folic acid, vitamin B12 and Alzheimer's disease: insights from meta-analyses. J Alzheimers Dis. 2015;46(3):777-90.

12. Zaric B, Obradovic $M$, Bajic V, Haidara $M$, Jovanovic M, Isenovic E. Homocysteine and hyperhomocysteinaemia. Curr Med Chem. 2019;26(16):2948-61.

13. Baroni L, Bonetto C, Rizzo G, Bertola C, Caberlotto L, Bazzerla G. Asocciation between cognitive impairment and vitamin B12, folate, and homocysteine status in elderly adults: a retrospective study. J Alzheimer's Dis. 2019 Jul 23;70(2):443-53.

14. Robinson N, Grabowski P, Rehman I. Alzhemer's disease pathogenesis: is there a role for folate? Mech Ageing Dev. 2018 Sep;174:86-94.

15. Araújo JR, Martel F, Borges N, Araújo JM, Keating $\mathrm{E}$. Folates and aging: role in mild cognitive impairment, dementia and depression. Ageing Res Rev. 2015 May;22:9-19.

16. O'Leary F, Allman M, Samman S. Vitamin B12 status, cognitive impairment and dementia: a systematic review of prospective cohort studies. British J Nutr. 2012 Dec 14;108(11):194861
17. von Arnim CA, Herbolsheimer F, Nikolaus T, Peter R, Biesalski HK, Ludolph AC, et al. Dietary antioxidants and dementia in a populationbased case-control study among older people in South Germany. J Alzheimers Dis. 2011 Dec $31 ; 31(4): 717-24$

18. Lanyau Domínguez $\mathrm{Y}$, Hernández $\mathrm{M}$, Macias Matos C, Zhou D. Is B vitamins deficiency associated with prevalence of Alzheimer's disease in Cuban elderly? Nutr Health. 2006 Jan 1;18(2):103-18

19. Gónzález L. Reforma económica en Cuba: mecanismos de desigualdad social y su repercusión en las personas de la Tercera Edad. INFOHEM. 2016;14(2):20-7. Spanish.

20. Llibre Rodríguez JJ, Valhuerdi Cepero A, Calvo M, García RM, Guerra M, Laucerique T, et al. Dementia and other chronic diseases in older adults in Havana and Matanzas: The 10/66 study in Cuba. MEDICC Rev. 2011 Oct;13(4):30-7.

21. Llibre Rodríguez JJ, Valhuerdi Cepero A, López Medina AM, Noriega Fernández L, Porto Álvarez R, Guerra Hernández MA, et al. Cuba's aging and Alzheimer longitudinal study. MEDICC Rev. 2017 Jan;19(1):31-5

22. Copeland JR, Dewey ME, Griffith-Jones HM. A computerized psychiatric diagnostic system and case nomenclature for elderly subjects: GMS and AGECAT. Psychol Med. 1986 Jan 31;16(1):89-99.

23. Hall KS, Hendrie HH, Brittain HM, Norton JA, Rodgers DD, Prince CS, et al. The development of a dementia screening interview in two distinct languages. Int J Methods Psychiatric Res. 1993;3:1-28.

24. Ganguli M, Chandra V, Gilbey JE, Ratcliff G, Sharma SD, Pandav R, et al. Cognitive test performance in a community-based non demented elderly sample in rural India: the Indo-US cross national dementia epidemiology study. Int Psychogeriatr. 1996 Winter;8(4):507-24.

25. Dewey ME, Copeland JR. Diagnosis of dementia from the history and aetiology schedule. Int $\mathrm{J}$ Geriatr Psychiatry. 2001 Sep;16(9):912-7.

26. American Psychiatric Association. Diagnostic and Statistical Manual of Mental Disorders. 4th ed. Washington, D.C.: American Psychiatry Association; 1994 Jan 15. 886 p.

27. Petersen RC, Stevens JC, Ganguli M, Tangalos EG, Cummings JL, Dekosky ST. Practice parameter: Early detection of dementia: Mild cognitive impairment (an evidence- based review). Report of the Quality Standards Subcommittee of the American Academy Neurology. Neurology. 2001 May 8;56(9):1133-42.

28. Van Den Berg $H$, Heseker $H$, Lamand $M$, Sandstrom B, Thurnham D. Flair Concerted Action No 10 Status Papers. Int J Vit Nutr Res. 1993;63:247-316.

29. Ueland PM, Refsum H, Stabler SP, Malinow MR, Andersson A, Allen RH. Total homocysteine in plasma or serum: methods and clinical applications. Clin Chem. 1993;39(9):1764-79.

30. Interdepartmental Committee on Nutrition for National Defense; National Institutes of Health. Serum Vitamin C (Ascorbic Acid)-Dinitrophenyl hydrazine method. In: Manual for Nutrition Surveys. 2 nd ed. Washington, D.C.: Interdepartmental Committee on Nutrition for National Defense; 1963. p. $117-9$

31. Thurnham DI, Smith E, Flora PS. Current LiquidChromatographic assay of retinol, alfa-tocopherol, beta-carotene, alpha-carotene, lycopene, and beta-cryptoxantin in plasma with tocopherol acetate as internal standard. Clin Chem. 1988;43:377-81.

32. Fidanza F. Nutritional Status Assessment. A manual for population studies. New York: Chapman \& Hall; 1991. p. 228-309.
33. Basu TK, Patel DR, Williams DC. A simplified microassay of transketolase in human blood. Int J Vit Res. 1974;44:319-26.

34. Selhub J, Jacques PF, Dallal G, Choumenkovitch $\mathrm{S}$, Rogers $\mathrm{G}$. The use of blood concentrations of vitamins and their respective functional indicators to define folate and vitamin B12 status. Food \& Nutr Bull. 2008;29:567-73.

35. World Medical Association [Internet]. FerneyVoltaire (FR): World Medical Association; c2020. Políticas. Políticas actuales. Declaración de Helsinki de la Asociación Médica Mundial. Principios éticos para las investigaciones médicas en seres humanos; 2017 Mar 21 [cited 2012 Nov 18]. Available at: https://www.wma.net/es/ policies-post/declaracion-de-helsinki-de-la-amm -principios-eticos-para-las-investigaciones-medi cas-en-seres-humanos/. Spanish

36. Smith $D$, Refsum $H$, Bottiglieri $T$, Fenech $M$, Hooshmand B, McCaddon A, et al. Homocysteine and Dementia: An International Consensus Statement. J Alzheimer's Dis. 2018;62:561-70.

37. Sharma M, Tiwart M, Kumar RK. Hyperhomocysteinemia: impact on neurodegenerative diseases. Basis \& Clin Pharmacol \& Toxicol. 2015;117(5):287-96.

38. Porter K, Hoey L, Hughes C, Ward M, McNulty $\mathrm{H}$. Causes, consequences and public health. Implications of low B-Vitamin status in ageing. Nutrients. 2016;8:725 DOI: 10.3390 .

39. Lopes da Silva S, Vellas B, Elemans S, Luchsinger J, Kamphuis P, Yaffe K, et al. Plasma nutrient status of patients with Alzheimer's disease: systematic review and meta-analysis. Alzheimer's \& Dementia. 2013:1-18.

40. Kim G, Kim H, Kim KN, Son JI, Kim SY, Tamura $\mathrm{T}$, et al. Relationship of cognitive function with $\mathrm{B}$ vitamin status, homocysteine, and tissue factor pathway inhibitor in cognitively impaired elderly: a cross sectional survey. J Alzheimers Dis. 2013;33(3):853-62.

41. Faux N, Ellis K, Porter L, Fowler C, Laws S, Martins $\mathrm{R}$, et al. Homocysteine, vitamin B12, and Folic acid levels in Alzheimer's disease, Mild Cognitive Impairment, and Healthy elderly: baseline characteristics in subjects of the Australian Imaging Biomarker Lifestyle study. J Alzheimer's Dis. 2011;27(4):909-22.

42. Ma F, Wu T, Zhao J, Ji L, Song A, Zhang M, et al. Plasma homocysteine and serum folate and vitamin B12 levels in Mild Cognitive Impairment and Alzheimer's Disease: a case-control study. Nutrients. 2017;9(7):pii:E725. DOI:10.3390/ nu9070725

43. Meng H, Li Y, Zhang W, Zhao Y, Niu X, Guo J The relationship between cognitive impairment and homocysteine in a B12 and folate deficient population in China: a cross- sectional study. Medicine (Baltimore). 2019;98(47):el7970.

44. Hyesook K, Ggotpin K, Wong J, Seong Y, Namsoo C. Association between intake of vitamins and cognitive function ibn elderly Koreans with cognitive impairment. Nutrition $\mathrm{J}$. 2014:13:118

45. Vinhquoc $\mathrm{K}$, Thi Hoáng $\mathrm{L}$. Role of Thiamine in Alzheimer's Disease. Am J Alzheimer's Dis \& Other Dementias. 2011;26 (8):588-98.

46. Hazell A, Faim S, Wertheimer G, Silva V, Marques $\mathrm{C}$. The impact of oxidative stress in thiamine deficiency: a multifactorial targeting issue. Neurochem Int. 2013;62:796-802.

47. de Wilde M, Vellas B, Girault E, Cetinyurek Yavuz A, Sijben JW. Lower brain and blood nutrient status in Alzheimer's disease: results from meta-analyses. Alzheimer Dement. 2017 Sep;3(3):416-31.

48. Hyeok J, Lee $\mathrm{H}$, Min Lee $\mathrm{K}$. The possible role of antioxidant vitamin C in Alzheimer's disease 
treatment and prevention. Am J Alzheimer's Dis \& Other Dementias. 2013;28(2):120-5.

49. Ono K, Yamada M. Vitamin A and Alzheimer's disease. Geriatr Gerontol. 2012;12:180-8.

\section{THE AUTHORS}

Yeneisy Lanyau-Domínguez (Corresponding author: ylanyau@infomed.sld.cu, yeneisy@inhem .sld.cu), biochemist with a master's degree in nutrition sciences and public health, and a doctorate in health sciences. Associate researcher, Biochemistry and Physiology Department, Nutrition and Food Hygiene Center (CNHA) of the National Hygiene, Epidemiology and Microbiology Institute (INHEM), Havana, Cuba. https:// orcid.org/0000-0002-1900-9852

Consuelo Macías-Matos, biochemist with a master's degree in nutrition sciences and public health, and a doctorate in chemistry. Senior researcher, Biochemistry and Physiology Department, CNHA, INHEM, Havana, Cuba. https://orcid.org/0000-0002-0241-7294

Juan de Jesús Llibre-Rodríguez, internist with a doctorate in medical sciences and a higher doctorate in science. Full professor and senior researcher, Alzheimer Research Center, Finlay Albarrán Faculty of Medicine, Medical University of Havana, Cuba. https://orcid .org/0000-0002-8215-3160
Gisela María Pita-Rodríguez, physician specializing in clinical biochemistry with a master's degree in environmental health. Associate researcher and associate professor, Biochemistry and Physiology Department, CNHA, INHEM, Havana, Cuba. https://orcid.org/0000-0002-5590-2461

Ramón Suárez-Medina, physician specializing in biostatistics. Associate researcher and associate professor, Epidemiology and Environmental Health Department, INHEM, Havana, Cuba. https://orcid.org/0000-0002-5311-5237

María Eugenia Quintero-Alejo, laboratory technician, Biochemistry and Physiology Department, CNHA, INHEM, Havana, Cuba. https://orcid.org/0000-0002-1093-6035

Lisseth Noriega-Fernández, psychiatrist with a master's degree in healthy longevity. Instructor, Marianao Community Mental Health Center, Havana, Cuba. https://orcid.org/0000-0003 $-3560-8625$

Milagros Guerra-Hernández, psychiatrist with a master's degree in healthy longevity. Assistant professor, 27 de Noviembre Polyclinic, Havana, Cuba. https://orcid.org/0000-0002-6835-1742

Marina Calvo-Rodríguez, psychiatrist with a master's degree in health psychology. Instruc- tor, La Lisa Community Health Center, Havana, Cuba.

Yvón Sánchez-Gil, psychiatrist with a master's degree in longevity studies. Assistant professor, Ana Betancourt Polyclinic, Havana, Cuba.

Milagros García-Klibanski, psychiatrist with a master's in social psychiatry. Full professor, Luyanó Polyclinic, Havana, Cuba.

Dania Herrera-Javier, laboratory technician, Biochemistry and Physiology Department, CNHA, INHEM, Havana, Cuba. https://orcid .org/0000-0002-0245-0879

Caridad Arocha-Oriol, laboratory technician, Biochemistry and Physiology Department, CNHA, INHEM, Havana, Cuba. https://orcid .org/0000-0001-5519-4592

Maybe Díaz-Domínguez, laboratory technician, Biochemistry and Physiology Department, CNHA, INHEM, Havana, Cuba. https://orcid .org/0000-0002-3199-2407

Submitted: June 26, 2020

Approved for Publication: September 9, 2020 Disclosures: None 